\title{
The effects of the aromatase inhibitor anastrozole on bone metabolism and cardiovascular risk indices in ovariectomized, androgen-treated female-to-male transsexuals
}

\author{
Mathijs C M Bunck ${ }^{1}$, Arno W F T Toorians ${ }^{1,2}$, Paul Lips ${ }^{1}$ and Louis J G Gooren ${ }^{1,2}$ \\ ${ }^{1}$ Department of Endocrinology and ${ }^{2}$ Section of Andrology, VU University Medical Center, PO Box 7057, 1007 MB Amsterdam, The Netherlands \\ (Correspondence should be addressed to L J G Gooren; Email: ljg.gooren@vumc.nl)
}

\begin{abstract}
Objective: Cases of men with estrogen resistance and aromatase deficiency have highlighted the effects of estrogens on bone metabolism, the cardiovascular system and biochemical variables of the metabolic syndrome. In eugonadal men, administration of an aromatase inhibitor induces a substantial elevation of LH and testosterone due to the decreased negative-feedback signal of estrogen and may thwart the interpretation of results. As there is no gonad for LH to act on, no increase of serum testosterone concentration will be seen in female-to-male transssexuals. The aim of this study was to investigate the effects of estrogen deprivation on bone metabolism and vascular parameters without the interference of counter-regulatory effects as seen in eugonadal men.

Design: Thirty ovariectomized female-to-male transsexuals participated in this double-blind, randomized trial. During 3 months, subjects received the aromatase inhibitor anastrozole $1 \mathrm{mg} / \mathrm{day}(n=16)$ or a placebo $(n=14)$ in addition to parenteral testosterone esters (Sustanon 250 every 2 weeks). Results: Serum $17 \beta$-estradiol $\left(\mathrm{E}_{2}\right)$ concentration fell significantly from $134.0 \pm 78.8$ to $77.7 \pm 130.6 \mathrm{pmol} / \mathrm{l}$ compared with placebo $(P<0.01)$. LH and FSH levels rose without the rise of testosterone levels observed in eugonadal men. Within the placebo group, $\mathrm{E}_{2}$ remained at baseline levels. Of the endpoint variables measured (bone metabolism and vascular parameters) no significant changes were observed compared with placebo, or within the anastrozole-treated group.

Conclusions: These results may indicate that the negative effects of estrogen deprivation in men only become manifest when the concentration falls below the levels induced by our intervention with anastrozole $(77 \mathrm{pmol} / \mathrm{l})$. This assumption is supported by the observation in the anastrozole group that, although effects of the reduction of serum $\mathrm{E}_{2}$ on vascular parameters could not be demonstrated in subjects as a group, there was a correlation between individual serum $\mathrm{E}_{2}$ and several vascular parameters.
\end{abstract}

European Journal of Endocrinology $154569-575$

\section{Introduction}

Traditionally conceptualized as 'female hormones', estrogens appear to have significant biological effects in the male. Estrogens have an important effect on the final phases of skeletal maturation and bone mineralization in puberty (1). In addition, from some studies in elderly men it appears that estrogen levels show a higher correlation with bone mineral density (BMD) than androgen levels (for review see Riggs et al. (2)) (3-5).

Impaired estrogen action in men leads to dyslipidemia and to impaired flow-mediated vasodilatation (FMD) in peripheral arteries in response to an ischemic stimulus, probably resulting from endothelial dysfunction (6). Evidence suggests that the effects of estrogen on the vascular system are not limited to the classic (slow) genomic pathway of steroid hormone action. Rapid, nitric oxide-mediated, vasodilatory effects occur after binding of circulating estradiol to a calcium-dependent cell surface estrogen receptor (7). Estrogen effects on the brain are also increasingly recognized (8).

Observation in men with aromatase deficiency show that these men have a complex dysmetabolic syndrome characterized by insulin resistance, diabetes mellitus type 2, acanthosis nigricans, liver steatosis hepatitis, and signs of precocious atherogenesis (9). Men with aromatase deficiency are extremely rare. Only four cases have been reported so far (9).

To further explore the role of estrogens in men, studies have been undertaken in eugonadal men in whom the endogenous estrogen production from 
androgens was suppressed by aromatase inhibitors. Upon administration of aromatase inhibitors, circulating estradiol levels decreased by 30-50\% (10). This decrease in circulating estradiol was associated with a rise of luteinizing hormone (LH) and testosterone levels due to a decreased negative-feedback signal of circulating estrogens to the hypothalamus and pituitary. The resulting increase in serum testosterone was in the order of $50-100 \%(11-13)$. The associated significant increase in circulating testosterone might thwart the analysis of the effects of reduction of circulating estrogen levels, since the biological systems upon which estrogen acts (bone, brain, cardiovascular system) are also subject to the action of androgens, of which the levels became strongly increased.

Therefore, we decided to explore the effects of aromatase inhibitor in ovariectomized female-to-male transssexuals who received androgen treatment. The dose administered is similar to doses given to hypogonadal men (parenteral testosterone esters i.m. every 2-3 weeks). As in men, part of the administered testosterone is aromatized to estradiol. When the aromatization of testosterone to estradiol is inhibited in female-tomale transssexuals, this is expected to lead to an increase of serum LH concentration; however, as there is no gonad for LH to act on, no increase of serum testosterone concentration will be seen.

\section{Subjects and methods}

\section{Subjects}

We included 30 ovariectomized female-to-male transsexuals who had received sex reassignment treatment at our clinic. Before sex reassignment they had been eugonadal biological female subjects with a normal female sexual differentiation, regular menstrual periods and a normal adult female endocrine profile. They received testosterone treatment parenterally (mixed testosterone esters, Sustanon 250; Organon, Oss, The Netherlands) every 2 weeks for 18-24 months. After hysterectomy and ovariectomy, androgen treatment was re-instituted with the same dose every $2-3$ weeks. Treatment with parenteral androgens results in strongly varying serum testosterone levels over time following administration (14). Testosterone patches, which generate a more stable serum testosterone concentration over time, were not (commercially) available in The Netherlands at the time of the study. Peripheral aromatization results in serum $17 \beta$-estradiol $\left(\mathrm{E}_{2}\right)$ values which are in the range of $100-200 \mathrm{pmol} / \mathrm{l}(15,16)$.

Patients were assigned at random to receive either the non-steroidal aromatase inhibitor anastrozole (Arimidex; Zeneca) $1 \mathrm{mg} /$ day for 12 weeks or to receive a placebo. Anastrozole $1 \mathrm{mg}$ inhibits aromatization by $96.1 \%$. A higher dosage does not result in a stronger inhibition of aromatization (10).
All subjects were healthy subjects without any clinical or biochemical evidence of bone or cardiovascular disease. Their age range was $21-46$ years. Severe smoking and/or heavy alcohol consumption were reasons for exclusion. Body mass index (BMI) ranged from 19.3 to $30.8 \mathrm{~kg} / \mathrm{m}^{2}$. To exclude differences in BMD due to race, only Caucasian subjects were selected, who constitute the vast majority of our population of transsexuals. All subjects gave their written informed consent and the study was approved by the ethical review board of the VU University Medical Center.

\section{Blood sampling and analysis}

Blood samples were obtained after an overnight fast between 0930 and $1030 \mathrm{~h}$. To minimize fluctuations in testosterone levels, patients were asked to visit the outpatient clinic 5 days after their mixed testosterone esters injection. All samples were centrifuged at $1500 \boldsymbol{g}$ and stored at $-80^{\circ} \mathrm{C}$ within $1 \mathrm{~h}$ after samples were obtained. After defrosting, all samples were analyzed within $1 \mathrm{~h}$.

Serum LH and follicle-stimulating hormone (FSH) concentrations were measured by a time-resolved immunofluorometric assay (Delfia; Wallac, Inc., Turku, Finland). The intra-assay coefficient of variation (CV) values for low serum LH and FSH levels were 3\%, the inter-assay $\mathrm{CV}$ values 7 and $5 \%$ respectively. The serum $\mathrm{E}_{2}$ concentration was measured using a double antibody RIA (DiaSorin Biomedica, Saluggia, Italy). The $\mathrm{E}_{2}$ intra- and inter-assay $\mathrm{CV}$ values were 7 and $8 \%$ respectively. The serum testosterone concentration was measured using the DPC Coat-a-Count RIA (DPC, Los Angeles, CA, USA). The intra- and inter-assay CV values for low testosterone serum levels were 6 and $7 \%$ respectively. The lower limits of detection for $\mathrm{LH}$, $\mathrm{FSH}, \mathrm{E}_{2}$ and testosterone were $0.3 \mathrm{U} / \mathrm{l}, 0.5 \mathrm{U} / \mathrm{l}$, $18 \mathrm{pmol} / \mathrm{l}$ and $1.0 \mathrm{nmol} / \mathrm{l}$ respectively.

Serum osteocalcin concentrations were measured by RIA using a kit from Biosource Medgenix Diagnostics (Fleurus, Belgium) (intra-assay CV 5\%; inter-assay CV $8 \%)$. With this assay, the intact molecule with no fragment cross-reaction is measured. 25-OH-vitamin D was assessed by a competitive binding protein assay (Diasorin MP Products, Stillwater, MN, USA; intraassay CV 9\%; inter-assay CV 9\%). Urinary deoxypyridinolone (DPD) was assessed by a competitive luminescence immunoassay (Bayer Diagnostics, Mijdrecht, The Netherlands). Standard laboratory tests were used to determine levels of glucose, insulin, total cholesterol, high-density lipoprotein (HDL), low-density lipoprotein (LDL), triglycerides, creatinine, calcium, phosphate, albumin and alkaline phosphatase and urinary creatinine excretion.

\section{Vascular measurements}

The distensibility coefficient (DC), reflecting intrinsic vascular wall elasticity, and the compliance coefficient (CC), 
reflecting buffering capacity of the vessel wall, were calculated from the arterial diameter (D) and changes in arterial diameter during the heart cycle $(\Delta \mathrm{D}$ or distension) and pulse pressure $(\Delta \mathrm{P})$ as follows: $\mathrm{DC}=(2$ $* \Delta \mathrm{D}) /(\mathrm{D} * \Delta \mathrm{P})$ and $\mathrm{CC}=(\Delta * \Delta \mathrm{D} * \mathrm{D}) /(2 * \Delta \mathrm{P}) \quad$ (17). All hemodynamic measurements were performed with a non-invasive ultrasound system as previously described (17). After at least $15 \mathrm{~min}$ of supine rest in a temperature-controlled quiet room. [Should 'All hemodynamic measurements were performed ...previously described (17). After at least $15 \mathrm{~min}$... .quiet room.' be 'All hemodynamic measurements were performed...previously described (17) after at least $15 \mathrm{~min} .$. quiet room.'?] All subjects refrained from smoking or consuming caffeine for at least $4 \mathrm{~h}$ before examination. The methods to assess endothelium-dependent FMD, nailfold capillary measurements and $24 \mathrm{~h}$ ambulatory blood pressure measurement, have been described in detail previously (18).

\section{Statistical analysis}

Values are presented as means \pm S.D. Because of the small study group, differences between the placebotreated and anastrozole-treated group were tested using the non-parametric Mann-Whitney test. To test within-treatment group changes, the Wilcoxon signed rank test was used. Also non-parametric Spearman correlation coefficients are shown. Statistical analysis was performed with SPSS 11.5 (SPSS, Chicago, IL, USA). $P$ values below 0.05 were considered significant.

\section{Results}

\section{Baseline characteristics and serum sex hormone levels}

Baseline characteristics and changes in serum sex hormone levels after 1 and 3 months are shown in Table 1. At baseline there were no differences in serum sex hormone levels, age and BMI between the subjects who received anastrozole and placebo. No difference in $\mathrm{E}_{2-}$ /testosterone ratio, a measure of aromatase activity, was seen between the two treatment groups at baseline. Three months of administration of anastrazole led to a significant fall of serum $\mathrm{E}_{2}$, compared with pre-treatment levels, as well as compared with placebo $(77.7 \pm 130.6$ vs $102.8 \pm 56.2 \mathrm{pmol} / \mathrm{l}$ respectively, $P=0.008)$. This effect was already reached after 1 month of treatment (Table 1). The anastrozoleinduced fall in serum $\mathrm{E}_{2}$ was accompanied by a significant $39.7 \%$ reduction in $\mathrm{E}_{2} /$ testosterone ratio (Table 1 ). As a response to the decrease in serum $\mathrm{E}_{2}$ levels in the anastrozole-treated group, serum LH and FSH levels increased (6.1 to $31.8 \mathrm{U} / \mathrm{l} ; P=0.001$ and 10.4 to $43.8 \mathrm{U} / \mathrm{l} ; \mathrm{P}=0.001$ respectively) as well as compared with placebo ( 11.3 to $31.8 \mathrm{U} / \mathrm{l} ; \mathrm{P}=0.004$ and 19.4 to $43.8 \mathrm{U} / \mathrm{l} ; \quad P=0.022$ respectively). As expected, there was no change in serum testosterone levels between the two treatment groups $(28.9 \pm 28.4$ vs $39.0 \pm 31.2 \mathrm{nmol} / \mathrm{l} ; \quad P=0.212$ respectively), since the subjects were ovariectomized. Individual subject data of changes in serum sex hormone concentrations are shown in Table 2.

\section{Bone metabolism indices}

After 3 months of treatment with anastrozole no statistically significant effects were observed on levels of serum calcium, phosphate, alkaline phosphate, osteocalcin and 25-OH-vitamin D or on levels of urinary DPD and the urinary DPD/creatinine ratio when compared with placebo (Table 3). No change in bone metabolism parameters was seen within the anastrazole treated group either (data not shown).

\section{Cardiovascular risk indices}

Compared with placebo (Table 3), as well as within the anastrozole-treated group (data not shown), no statistically significant changes were observed in serum C-reactive protein, total cholesterol, HDL-cholesterol,

Table 1 Study characteristics and changes in serum sex hormone concentrations before and after 3 months of anastrozole administration. Means \pm S.D. $P$-values are given to compare baseline results with results after 3 months (Mann-Whitney test).

\begin{tabular}{|c|c|c|c|c|c|c|c|c|c|}
\hline & \multicolumn{3}{|c|}{ Baseline } & \multicolumn{3}{|c|}{1 month } & \multicolumn{3}{|c|}{3 months } \\
\hline & $\begin{array}{l}\text { Placebo } \\
(n=14)\end{array}$ & $\begin{array}{l}\text { Anastrozole } \\
(n=16)\end{array}$ & $P$-value & $\begin{array}{l}\text { Placebo } \\
(n=14)\end{array}$ & $\begin{array}{l}\text { Anastrozole } \\
(n=16)\end{array}$ & $P$-value & $\begin{array}{l}\text { Placebo } \\
(n=14)\end{array}$ & $\begin{array}{c}\text { Anastrozole } \\
(n=16)\end{array}$ & $P$-value \\
\hline Age & $34.8 \pm 8.3$ & $37.1 \pm 7.0$ & NS & - & - & - & - & - & - \\
\hline Body mass index & $24.6 \pm 3.5$ & $25.6 \pm 2.9$ & NS & - & - & - & - & - & - \\
\hline $\mathrm{LH}(\mathrm{U} / \mathrm{l})$ & $9.4 \pm 15.0$ & $6.1 \pm 11.1$ & NS & $10.6 \pm 18.2$ & $19.0 \pm 19.7$ & NS & $11.3 \pm 19.4$ & $31.8 \pm 20.5$ & $<0.01$ \\
\hline FSH (Ú/l) & $20.4 \pm 28.8$ & $10.4 \pm 16.2$ & NS & $19.5 \pm 30.3$ & $34.9 \pm 23.8$ & NS & $19.4 \pm 30.8$ & $43.8 \pm 28.5$ & 0.02 \\
\hline Testosterone $(\mathrm{nmol} / \mathrm{l})$ & $44.5 \pm 40.1$ & $41.1 \pm 34.1$ & NS & $30.6 \pm 21.7$ & $37.1 \pm 18.2$ & NS & $29.0 \pm 28.4$ & $39.0 \pm 31.2$ & NS \\
\hline $\mathrm{E}_{2}(\mathrm{pmol} / \mathrm{l})$ & $102.8 \pm 55.1$ & $134.0 \pm 78.8$ & NS & $109.8 \pm 62.2$ & $32.1 \pm 21.7$ & $<0.001$ & $102.8 \pm 56.2$ & $77.7 \pm 130.6$ & $<0.01$ \\
\hline SHBG (nmol/l) & $29.8 \pm 12.5$ & $30.9 \pm 15.4$ & NS & $30.0 \pm 13.5$ & $30.4 \pm 15.9$ & NS & $31.0 \pm 13.8$ & $29.8 \pm 14.7$ & NS \\
\hline Delta $E_{2}^{\prime}(p m o l / l)$ & - & - & - & $7.0 \pm 78.5$ & $-101.9 \pm 73.4$ & $<0.0001$ & $0.01 \pm 67.2$ & $-56.3 \pm 151.4$ & $<0.0001$ \\
\hline $\begin{array}{l}\mathrm{E}_{2} / \text { testosterone } \\
\text { ratio }(\mathrm{pmol} / \mathrm{nmol})\end{array}$ & $3.5 \pm 2.0$ & $3.7 \pm 1.8$ & NS & $4.4 \pm 2.0$ & $1.3 \pm 1.8$ & $<0.0001$ & $5.2 \pm 3.0$ & $1.1 \pm 0.8$ & $<0.0001$ \\
\hline
\end{tabular}


Table 2 Effect of 3 months of administration of anastrozole $(n=16)$ and placebo $(n=14)$ on serum LH, testosterone and $\mathrm{E}_{2}$ concentrations as well as $\mathrm{E}_{2} /$ testosterone ratio. All values are individual differences after 3 months of anastrozole or placebo.

\begin{tabular}{|c|c|c|c|c|c|}
\hline Subject & $\begin{array}{l}\text { Treatment } \\
\text { arm }\end{array}$ & $\begin{array}{c}\text { Delta LH } \\
\text { (U/I, baseline }-3 \text { months) }\end{array}$ & $\begin{array}{c}\text { Delta testosterone } \\
\text { (nmol/l, baseline }-3 \text { months) }\end{array}$ & $\begin{array}{c}\text { Delta } \mathbf{E}_{2} \\
\text { (pmol/l, baseline }-3 \text { months) }\end{array}$ & $\begin{array}{r}\text { Delta } \mathbf{E}_{2} / \text { testosterone } \\
\text { (baseline }-3 \text { months) }\end{array}$ \\
\hline 1 & Placebo & -3.06 & -4.15 & -11.10 & 7.11 \\
\hline 2 & Placebo & -2.10 & -121.79 & -81.40 & 1.75 \\
\hline 3 & Placebo & -0.87 & -2.72 & 2.70 & 2.27 \\
\hline 4 & Placebo & -0.70 & 5.75 & 22.00 & 0.11 \\
\hline 5 & Placebo & -0.49 & 3.57 & 12.60 & -0.37 \\
\hline 6 & Placebo & -0.47 & -0.22 & 24.70 & 1.06 \\
\hline 7 & Placebo & -0.35 & -8.32 & 80.60 & 4.00 \\
\hline 8 & Placebo & -0.35 & 92.07 & 107.20 & -2.33 \\
\hline 9 & Placebo & 0.00 & -47.55 & -129.40 & 0.65 \\
\hline 10 & Placebo & 0.00 & -26.67 & -52.60 & 0.38 \\
\hline 11 & Placebo & 0.00 & 20.74 & 81.60 & -2.27 \\
\hline 12 & Placebo & 0.10 & -1.28 & 37.10 & 1.17 \\
\hline 13 & Placebo & 10.00 & -45.75 & -26.00 & 1.62 \\
\hline 14 & Placebo & 24.82 & -80.88 & -67.90 & 8.36 \\
\hline 15 & Anastrozole & -5.59 & -5.46 & -20.30 & -0.37 \\
\hline 16 & Anastrozole & 0.00 & 45.80 & -269.20 & -5.73 \\
\hline 17 & Anastrozole & 0.55 & 35.80 & -54.80 & -7.46 \\
\hline 18 & Anastrozole & 2.05 & -68.00 & -208.40 & -1.28 \\
\hline 19 & Anastrozole & 4.92 & -1.78 & -30.10 & -1.99 \\
\hline 20 & Anastrozole & 26.85 & 90.27 & 79.90 & -2.35 \\
\hline 21 & Anastrozole & 28.31 & -46.00 & -102.30 & -0.73 \\
\hline 22 & Anastrozole & 28.78 & -35.89 & -180.70 & -2.60 \\
\hline 23 & Anastrozole & 31.00 & -55.05 & -125.10 & -1.08 \\
\hline 24 & Anastrozole & 32.00 & -10.00 & -158.40 & -2.70 \\
\hline 25 & Anastrozole & 35.90 & -18.02 & -123.40 & -2.11 \\
\hline 26 & Anastrozole & 39.73 & -12.45 & -68.50 & -2.59 \\
\hline 27 & Anastrozole & 43.00 & 8.82 & -112.10 & -2.82 \\
\hline 28 & Anastrozole & 47.60 & 6.76 & 169.00 & 4.85 \\
\hline 29 & Anastrozole & 47.80 & 31.21 & -45.00 & -3.86 \\
\hline 30 & Anastrozole & 48.18 & 0.88 & 348.20 & 76.41 \\
\hline
\end{tabular}

Table 3 Parameters of bone metabolism and cardiovascular risk indices before and after 3 months of anastrozole $(n=16)$ and placebo $(n=14)$ administration. All values are means \pm S.D. $P$-values are given to compare baseline results with results after 3 months (Mann-Whitney test).

\begin{tabular}{|c|c|c|c|c|c|c|}
\hline & \multicolumn{3}{|c|}{ Baseline } & \multicolumn{3}{|c|}{3 months } \\
\hline & Placebo & Anastrozole & $P$-value & Placebo & Anastrozole & $P$-value \\
\hline \multicolumn{7}{|l|}{ Bone metabolism } \\
\hline Calcium (mmol/l) & $2.38 \pm 0.08$ & $2.31 \pm 0.09$ & NS & $2.35 \pm 0.08$ & $2.35 \pm 0.08$ & NS \\
\hline Phosphate $(\mathrm{mmol} / \mathrm{l})$ & $0.92 \pm 0.19$ & $0.93 \pm 0.17$ & NS & $0.88 \pm 0.20$ & $0.99 \pm 0.13$ & NS \\
\hline Alkaline phosphatase (U/l) & $62.21 \pm 15.5$ & $60.75 \pm 14.35$ & NS & $62.50 \pm 16.5$ & $63.56 \pm 15.85$ & NS \\
\hline Albumin $(g / l)$ & $43.0 \pm 4.7$ & $40.6 \pm 3.85$ & NS & $42.43 \pm 2.2$ & $42.06 \pm 2.77$ & NS \\
\hline Creatinine $(\mu \mathrm{mol} / \mathrm{l})$ & $99.07 \pm 10.1$ & $93.63 \pm 10.42$ & NS & $95.29 \pm 10.9$ & $95.19 \pm 7.64$ & NS \\
\hline Osteocalcin (nmol/l) & $1.80 \pm 0.63$ & $1.63 \pm 0.62$ & NS & $2.04 \pm 0.96$ & $1.62 \pm 0.70$ & NS \\
\hline $25-\mathrm{OH}$-vitD (nmol/l) & $71.54 \pm 24.41$ & $63.13 \pm 22.54$ & NS & $52.57 \pm 15.60$ & $57.92 \pm 28.02$ & NS \\
\hline Urinary DPD (nmol//) & $64.18 \pm 42.95$ & $62.06 \pm 39.69$ & NS & $81.55 \pm 70.28$ & $78.37 \pm 36.26$ & NS \\
\hline Urinary creatinine $(\mathrm{nmol} / \mathrm{l})$ & $11.16 \pm 6.06$ & $11.29 \pm 5.99$ & NS & $12.19 \pm 6.77$ & $13.79 \pm 5.78$ & NS \\
\hline Urinary DPD/creatinine ratio & $5.84 \pm 2.60$ & $5.35 \pm 2.07$ & NS & $6.22 \pm 4.22$ & $5.70 \pm 1.55$ & NS \\
\hline \multicolumn{7}{|l|}{ Cardiovascular risk indices } \\
\hline Glucose $(\mathrm{mmol} / \mathrm{l})$ & $4.8 \pm 0.3$ & $4.8 \pm 0.8$ & NS & $4.9 \pm 0.6$ & $5.0 \pm 0.8$ & NS \\
\hline Insulin (pmol/l) & $67.0 \pm 27.57$ & $55.06 \pm 28.72$ & NS & $64.93 \pm 35.0$ & $66.63 \pm 28.35$ & NS \\
\hline C-reactive protein (mg/l) & $4.29 \pm 1.66$ & $13.33 \pm 20.85$ & NS & $3.95 \pm 2.59$ & $5.28 \pm 2.27$ & NS \\
\hline Cholesterol (mmol/l) & $4.8 \pm 1.0$ & $4.8 \pm 1.1$ & NS & $4.8 \pm 0.9$ & $4.9 \pm 1.1$ & NS \\
\hline HDL-cholesterol $(\mathrm{mmol} / \mathrm{l})$ & $1.27 \pm 0.26$ & $1.10 \pm 0.33$ & NS & $1.30 \pm 0.27$ & $1.12 \pm 0.27$ & NS \\
\hline LDL-cholesterol (mmol/l) & $2.8 \pm 0.8$ & $3.0 \pm 0.8$ & NS & $3.0 \pm 0.8$ & $3.0 \pm 0.8$ & NS \\
\hline Triglycerides $(\mathrm{mmol} / \mathrm{l})$ & $1.51 \pm 1.16$ & $1.69 \pm 1.67$ & NS & $1.16 \pm 0.58$ & $1.87 \pm 1.83$ & NS \\
\hline
\end{tabular}

www.eje-online.org 
LDL-cholesterol, triglycerides, insulin and glucose concentrations after 3 months of anastrozole administration.

None of the vascular studies (hemodynamic measurements (Table 4), microvascular measurements, FMD and $24 \mathrm{~h}$ ambulatory blood pressure measurement (data not shown)) showed an effect of the reduction of serum $\mathrm{E}_{2}$ compared with placebo. Also, no (statistically significant) effects were seen within the anastrozoletreated group (data not shown). Interestingly enough, a significant positive correlation between the reduction in serum $\mathrm{E}_{2}$ concentration and change in CC (Spearman's rho $=0.62 ; P=0.018$ ) and the DC (Spearman's rho $0.61 ; P=0.021$ ) of the common carotid artery was seen within the anastrozole-treated group following 3 months of anastrozole administration (Fig. 1).

\section{Discussion}

Estrogens have significant biological effects in men. These effects include effects on the cardiovascular system and bone metabolism (19). So far, several studies have been conducted on the effects of estrogen reduction with aromatase inhibitors in eugonadal men. However, in these studies suppression of $E_{2}$ concentration was accompanied by an increase in serum testosterone concentration due to the decreased negative feedback of circulating estrogens on the hypothalamus and pituitary gland. This increase in testosterone concentration might confound the effects of the reduced estrogen levels. Our study assessed the effects of a reduction of serum $\mathrm{E}_{2}$ induced by administration of anastrozole in a population which does not respond with a rise in serum testosterone levels, which has been observed in other studies with anastrozole in eugonadal (11) and borderline eugonadal men $(12,13)$.

We observed a mean fall in serum $\mathrm{E}_{2}$ of approximately $42 \%$ (from $134.0 \pm 78.8$ to $77.7 \pm 130.6 \mathrm{pmol} / \mathrm{l}$ ), which is similar to other studies using an aromatase inhibitor in men (11-13). The individual changes in serum $\mathrm{E}_{2}$ varied strongly between subjects receiving anastrozole (Table 2). We found that subjects with the highest baseline serum $E_{2}$ levels showed the largest reduction in serum $\mathrm{E}_{2}$ levels. Administration of the aromatase inhibi- tor resulted in a $39.7 \%$ reduction in $\mathrm{E}_{2} /$ testosterone ratio (Table 2). Interestingly, two individuals showed a large increase in $\mathrm{E}_{2} /$ testosterone, indicating possible non-compliance. Re-analysis without these subjects showed an even larger effect on $\mathrm{E}_{2} /$ testosterone (a $67.4 \%$ reduction), although without having an effect on the study's endpoints. The above findings of a reduction in serum $\mathrm{E}_{2}$ levels and the increased serum LH and FSH indicate a biological effect of the intervention. The absence of a significant effect on the studied endpoints (with and without the two possible non-compliant subjects) might also be an effect of the non-physiological fluctuations in serum testosterone. Parenterally administered mixed testosterone esters are known to generate strongly fluctuating levels of testosterone, with high supraphysiological testosterone levels during the first days after injection falling rapidly to subnormal levels. To cope with this imperfection in study design, the subjects were sampled on the 5th day after the testosterone injection. Probably as a result, there were throughout the study no differences in serum testosterone concentration between the two study groups. Interestingly, sex hormone-binding globulin (SHBG) levels, a variable affected by circulating estrogens and androgens, were not affected by our intervention. This may indicate insufficient aromatase inhibition to have an effect on this variable, although effects on serum LH and FSH were noted (Tables 1 and 2). The lack of changes in SHBG concentration could also be due to the high individual peaks in testosterone levels.

In this study we analyzed the effects of administration of testosterone together with anastrozole in ovariectomized subjects who had been eugonadal females before and we compared the results with literature data on men. We are not aware of data that demonstrate a sex difference in sensitivity to estrogen action, and our extensive studies on the metabolic effects of cross-sex hormone administration to transsexuals offer no clues to this effect. After the intervention with anastrozole, a correlation could be demonstrated between serum $E_{2}$ and effects on vascular parameters, which seems to suggest that biological effects of a reduction of serum $E_{2}$ manifest themselves only when serum $\mathrm{E}_{2}$ falls below a critical level. In support of this

Table 4 Effect of 3 months of administration of anastrozole $(n=16)$ and placebo $(n=14)$ on hemodynamic measurement of the common carotid artery. All values are means \pm S.D. $P$-values are given to compare baseline results with results after 3 months (Mann-Whitney test).

\begin{tabular}{|c|c|c|c|c|c|c|}
\hline & \multicolumn{3}{|c|}{ Baseline } & \multicolumn{3}{|c|}{3 months } \\
\hline & Placebo & Anastrozole & $P$-value & Placebo & Anastrozole & $P$-value \\
\hline Diameter (mm) & $6.8 \pm 0.7$ & $9.9 \pm 0.3$ & NS & $6.8 \pm 0.6$ & $6.9 \pm 0.4$ & NS \\
\hline Distention $(\mu \mathrm{m})$ & $600.0 \pm 142.0$ & $516.3 \pm 146.5$ & NS & $556.2 \pm 132.5$ & $516.8 \pm 128.1$ & NS \\
\hline Compliance coefficient $\left(\mathrm{mm}^{2 *} \mathrm{kPa}^{-1}\right)$ & $1.1 \pm 0.3$ & $0.9 \pm 0.2$ & NS & $1.0 \pm 0.2$ & $0.9 \pm 0.3$ & NS \\
\hline Distensibility coefficient $\left(10^{-3_{*}} \mathrm{kPa}^{-1}\right)$ & $29.3 \pm 9.5$ & $24.3 \pm 5.9$ & NS & $28.1 \pm 7.0$ & $24.0 \pm 7.2$ & NS \\
\hline Intima-media thickness (mm) & $0.6 \pm 0.1$ & $0.7 \pm 0.1$ & NS & $0.6 \pm 0.1$ & $0.6 \pm 0.1$ & NS \\
\hline
\end{tabular}



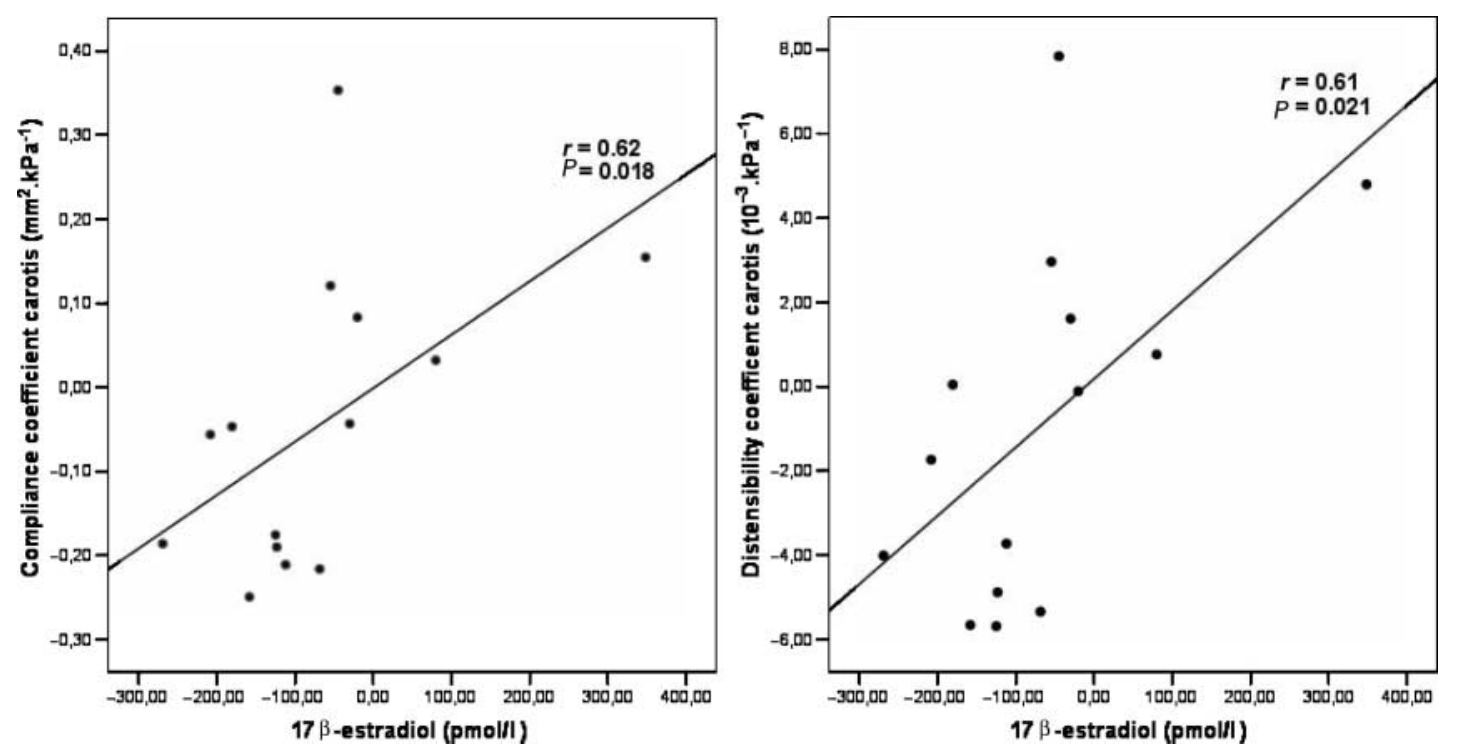

Figure 1 Scatter plot showing the association between changes (baseline vs 3 months) in serum $E_{2}$ levels and CC and DC of the common carotid artery after 3 months of anastrozole administration. $r=$ Spearman's rho.

assumption, no correlation was seen in the placebotreated group, making an estrogenic effect plausible.

Our findings are in agreement with a recent study of anastrozole administration to elderly mildly hypogonadal men (13). Similarly, there were no effects of this intervention on vascular factors or insulin sensitivity in the group receiving anastrozole, but a correlation between serum $\mathrm{E}_{2}$ and serum triglycerides could be demonstrated (13), which was not, however, apparent in our study. Others have found in eugonadal men, with a similar dose of anastrozole, that FMD was decreased (6), which did not appear in our analysis, either as a group effect or in the correlation of serum $\mathrm{E}_{2}$ with vascular effects. Men with congenital aromatase deficiency and clinical symptoms of estrogen deficiency have serum $E_{2}$ levels below $30 \mathrm{pmol} / \mathrm{l}$ (20-22). These symptoms showed an improvement when serum $\mathrm{E}_{2}$ levels were raised to above $80 \mathrm{pmol} / \mathrm{l}$ (20-22). Studies on osteoporosis in elderly men have also found that serum $\mathrm{E}_{2}$ below $40 \mathrm{pmol} / \mathrm{l}$ are an etiological factor (for review see Riggs et al. (2)). This value is well below the levels of serum $E_{2}$ induced by anastrozole in our study. So, the lack of demonstrable effects of the reduction in serum $E_{2}$ in our study must, in all likelihood, be ascribed to the fact that in most subjects serum $E_{2}$ remained above a threshold below which manifestations of estrogen deficiency become apparent. This assumption is supported by the correlation that could be established between the fall in serum $E_{2}$ and effects on parameters of vascular function.

In conclusion, cases of men with estrogen resistance and aromatase deficiency have highlighted the role of estrogens on bone metabolism, the cardiovascular system and biochemical variables related to the meta- bolic syndrome. Estrogen replacement producing serum $\mathrm{E}_{2}$ levels above $80 \mathrm{pmol} / \mathrm{l}$ improve these manifestations of estrogen deficiency. Conversely, a reduction of serum $E_{2}$ to levels that remain in the order of $70-80 \mathrm{pmol} / \mathrm{l}$ is without much of an effect. Estrogen deficiency in men probably leads to clinical manifestations when the serum $\mathrm{E}_{2}$ concentration falls below $70-80 \mathrm{pmol} / \mathrm{l}$. Our study suffered from methodological imperfections, notably the strong fluctuation in serum testosterone, the substrate of aromatization. Replication studies with more stable modes of testosterone administration (i.e. transdermal testosterone patches and longacting testosterone undecanoate injections) are needed to provide answers on the effects of estrogens on male physiology.

\section{References}

1 Bouillon R, Bex M, Vanderschueren D \& Boonen S. Estrogens are essential for male pubertal periosteal bone expansion. Journal of Clinical Endocrinology and Metabolism 200489 6025-6029.

2 Riggs BL, Khosla S \& Melton LJ III. Sex steroids and the construction and conservation of the adult skeleton. Endocrine Reviews $200223279-302$.

3 Gennari L, Merlotti D, Martini G, Gonnelli S, Franci B, Campagna S, Lucani B, Dal Canto N, Valenti R, Gennari C \& Nuti R. Longitudinal association between sex hormone levels, bone loss, and bone turnover in elderly men. Journal of Clinical Endocrinology and Metabolism $2003 \mathbf{8 8} 5327-5333$.

4 Gennari L, Nuti R \& Bilezikian JP. Aromatase activity and bone homeostasis in men. Journal of Clinical Endocrinology and Metabolism $2004895898-5907$.

5 van Pottelbergh I, Goemaere S, Zmierczak H \& Kaufman JM. Perturbed sex steroid status in men with idiopathic osteoporosis and their sons. Journal of Clinical Endocrinology and Metabolism 2004 $894949-4953$. 
6 Lew R, Komesaroff P, Williams M, Dawood T \& Sudhir K. Endogenous estrogens influence endothelial function in young men. Circulation Research 200393 1127-1133.

7 Cho JJ, Cadet P, Salamon E, Mantione K \& Stefano GB. The nongenomic protective effects of estrogen on the male cardiovascular system: clinical and therapeutic implications in aging men. Medical Science Monitor 20039 RA63-RA68.

8 Veiga S, Melcangi RC, Doncarlos LL, Garcia-Segura LM \& Azcoitia I. Sex hormones and brain aging. Experimental Gerontology $2004391623-1631$.

9 Rochira V, Balestrieri A, Madeo B, Spaggiari A \& Carani C. Congenital estrogen deficiency in men: a new syndrome with different phenotypes; clinical and therapeutic implications in men. Molecular and Cellular Endocrinology 2002193 19-28.

10 Mauras N, Lima J, Patel D, Rini A, di Salle E, Kwok A \& Lippe B. Pharmacokinetics and dose finding of a potent aromatase inhibitor, aromasin (exemestane), in young males. Journal of Clinical Endocrinology and Metabolism $2003885951-5956$.

11 Mauras N, O’Brien KO, Klein KO \& Hayes V. Estrogen suppression in males: metabolic effects. Journal of Clinical Endocrinology and Metabolism $2000 \mathbf{8 5} 2370-2377$.

12 Leder BZ, Rohrer JL, Rubin SD, Gallo J \& Longcope C. Effects of aromatase inhibition in elderly men with low or borderline-low serum testosterone levels. Journal of Clinical Endocrinology and Metabolism 200489 1174-1180.

13 Dougherty RH, Rohrer JL, Hayden D, Rubin SD \& Leder BZ. Effect of aromatase inhibition on lipids and inflammatory markers of cardiovascular disease in elderly men with low testosterone levels. Clinical Endocrinology 200562 228-235.

14 Behre HM \& Nieschlag E. Comparative pharmacokinetics of testosterone esters. In Testosterone: Action, Deficiency and Substitution, edn 2, pp 329-348. Eds E Nieschlag \& HM Behre. Berlin: Springer Verlag, 1998.

15 Spinder T, Spijkstra JJ, van den Tweel JG, Burger CW, van Kessel H, Hompes PG \& Gooren LJ. The effects of long term testosterone administration on pulsatile luteinizing hormone secretion and on ovarian histology in eugonadal female to male transsexual subjects. Journal of Clinical Endocrinology and Metabolism 1989 $69151-157$.
16 Spinder T, Spijkstra JJ, Gooren LJ, Hompes PG \& van Kessel H. Effects of long-term testosterone administration on gonadotropin secretion in agonadal female to male transsexuals compared with hypogonadal and normal women. Journal of Clinical Endocrinology and Metabolism 198968 200-207.

17 Giltay EJ, Lambert J, Gooren LJ, Elbers JM, Steyn M \& Stehouwer CD. Sex steroids, insulin, and arterial stiffness in women and Men. Hypertension 199934 590-597.

18 Schram MT, Stam F, de Jongh RT, De Vries G, van Dijk RA, Serne EH, Lampe D, Nanayakkara PW, Tushuizen ME, Scheffer PG, Schalkwijk CG, Kamper AM \& Stehouwer CD. The effect of calcium dobesilate on vascular endothelial function, blood pressure, and markers of oxidation in obese male smokers: a placebo-controlled randomised clinical trial. Atherosclerosis $200317059-72$.

19 de Ronde W, Pols HA, van Leeuwen JP \& de Jong FH. The importance of oestrogens in males. Clinical Endocrinology $2003 \mathbf{5 8}$ 529-542.

20 Rochira V, Faustini-Fustini M, Balestrieri A \& Carani C. Estrogen replacement therapy in a man with congenital aromatase deficiency: effects of different doses of transdermal estradiol on bone mineral density and hormonal parameters. Journal of Clinical Endocrinology and Metabolism 200085 1841-1845.

21 Herrmann BL, Saller B, Janssen OE, Gocke P, Bockisch A, Sperling H, Mann K \& Broecker M. Impact of estrogen replacement therapy in a male with congenital aromatase deficiency caused by a novel mutation in the CYP19 gene. Journal of Clinical Endocrinology and Metabolism 200287 5476-5484.

22 Maffei L, Murata Y, Rochira V, Tubert G, Aranda C, Vazquez M, Clyne CD, Davis S, Simpson ER \& Carani C. Dysmetabolic syndrome in a man with a novel mutation of the aromatase gene: effects of testosterone, alendronate, and estradiol treatment. Journal of Clinical Endocrinology and Metabolism 200489 61-70.

Received 6 June 2005

Accepted 19 January 2006 